\title{
Analisis Aktivitas Otot Dengan Perbedaan Jenis Kelamin Pada Postur Tangan Menggunakan Surface Electromyography
}

\author{
Indah Pratiwi ${ }^{1,2 *}$, Purnomo $^{2}$, Rini Dharmastiti ${ }^{2}$, Lientje Setyawati ${ }^{2}$
}

\begin{abstract}
This study aims to analyze the muscle activity in the upper body of the hand posture. Measurements are made when the workers perform the activities of making pottery in a sitting position. Measurements use surface electromyography and differentiate sex between men and women. The research steps were: (1) worker capture resulted in ten postures, (2) determination of muscle influences, namely: extensor carpi radialis muscle, extensor carpi ulnar muscle, extensor of the wrist muscle, biceps brachii muscle, flexor carpi radialis muscle, and (5) calculate using root mean square (RMS) and RMS value index RMS value and deviation index RMS value of male - higher than women in each muscle and in every posture.
\end{abstract}

Keywords: hand posture, sEMG, gender, root mean square.

\begin{abstract}
Abstrak, Penelitian ini bertujuan untuk menganalisis aktivitas otot pada tubuh bagian atas yaitu postur tangan. Pengukuran dilakukan pada saat pekerja melakukan aktivitas pembuatan gerabah pada posisi duduk. Pengukuran menggunakan surface electromyography dan membedakan jenis kelamin antara laki-laki dan perempuan. Langkah penelitian adalah (1) hasil capture pekerja terdapat sepuluh postur tangan, (2) penentuan otot yang berpengaruh, yaitu: otot extensor carpi radialis, otot extensor carpi ulnaris, otot extensor of the wrist, otot biceps brachii, otot flexor carpi radialis, dan otot flexor carpi ulnaris (3) mengukur aktvitas otot dengan postur tangan diam selama 5 detik, (4) pengukuran aktivitas otot menggunakan sEMG, (5) menghitung menggunakan root mean square (RMS) dan indeks nilai RMS Nilai RMS dan indeks simpangan Nilai RMS laki-laki lebih tinggi dibanding perempuan disetiap otot dan disetiap postur tangan.
\end{abstract}

Kata Kunci: Postur Tangan, sEMG, Jenis Kelamin, Root Mean Square.

\section{Pendahuluan}

Pekerja sering mengalami kelelahan dengan sikap statis dan dilakukan berulang tanpa memperhatikan postur yang tepat sehingga beresiko mengalami work-related musculoskeletal disorders (WMSDs). Biasanya WMSDs dirasakan setelah keluhan terakumulasi dan bisa mengganggu kesehatan para pekerja. Penyebab timbulnya WMSDs

\footnotetext{
1 Jurusan Teknik Industri, Universitas Muhammadiyah Surakarta, Jln. Ahmad Yani, Pabelan, Surakarta, 57162.

${ }^{2}$ Departemen Teknik Mesin dan Industri, Universitas Gadjah Mada, Jln. Jl. Grafika No. 2, Yogyakarta.

"email: indah.pratiwi@ums.ac.id
}

Diajukan: 15-09-2017

Diperbaiki: 05-12-2017 dikarenakan oleh lingkungan kerja yang tidak sesuai dengan kondisi normal, sehingga menyebabkan pekerja melakukan pergerakan tubuh yang melebihi batas kemampuan otot. Timbulnya berbagai keluhan tersebut dapat disebabkan karena kurangnya pengetahuan tentang ergonomi dan postur kerja yang kurang fisiologis berupa posisi kaki sering menekuk untuk menggerakkan alat putar, punggung terlalu membungkuk, dan hiperekstensi leher yang sering dihubungkan dengan keluhan WMSDs, tangan dan pergelangan menekuk dan duduk terlalu lama.

Pada penelitian ini pendekatan ergonomi dilakukan dengan melakukan pengukuran aktivitas otot menggunakan surface electromyography (sEMG) pada postur tangan pada pekerja gerabah dengan 
mempertimbangkan aspek tubuh bagian atas.

Kelelahan otot merupakan suatu fenomena kompleks berkaitan dengan penyebab, mekanisme dan manifestasi bentuk pekerjaan. Hasil pengembangan dari suatu rangkaian metabolisme, perubahan struktural dan energi pada otot berkaitan dengan berkurangnya oksigen dan suplai unsur gizi melalui aliran darah, dan juga perubahan pada sistem syaraf. Beban statis bagian belakang tubuh pada level terendah yang berlangsung lama pada posisi duduk hipotesisnya dapat mempengaruhi otot bagian belakang tubuh menjadi kurang baik. Aktivitas pada level terendah dalam waktu yang lama dari otot dapat mempengaruhi aktivitas otot lebih tinggi pada kelompok otot lainnya.

Penyakit pada sistem muskuloskeletal adalah salah satu penyebab yang paling sering dari ketidakmampuan kerja dan pensiun dini, diakibatkan karena beban berlebihan dan kelelahan pada sistem muskuloskeletal (Bartuzi et al., 2015). sEMG telah menjadi metode yang umum digunakan untuk menilai beban otot dan kelelahan otot. Kelelahan otot dinilai berdasarkan sinyal parameter EMG yang ditentukan dalam waktu (amplitudo sinyal EMG), mean power frequency (MPF) dan metal factor (MF) domain. Parameter yang digambarkan sebagai parameter global dan nilainya berubah karena proses kelelahan otot, selain itu juga dipengaruhi oleh tingkat kekuatan, unit motorik, proporsi serat otot, jenis otot, dan panjang otot (Bartuzi, dkk., 2015). Gangguan muskuloskeletal, terutama ekstremitas atas jadi perhatian di industri modern, dan faktor risiko fisik seperti kekuatan dan postur yang terkait dengan penyebabnya (Finneran \& Sullivan, 2013).

Artikel ini membahas tentang perbedaan

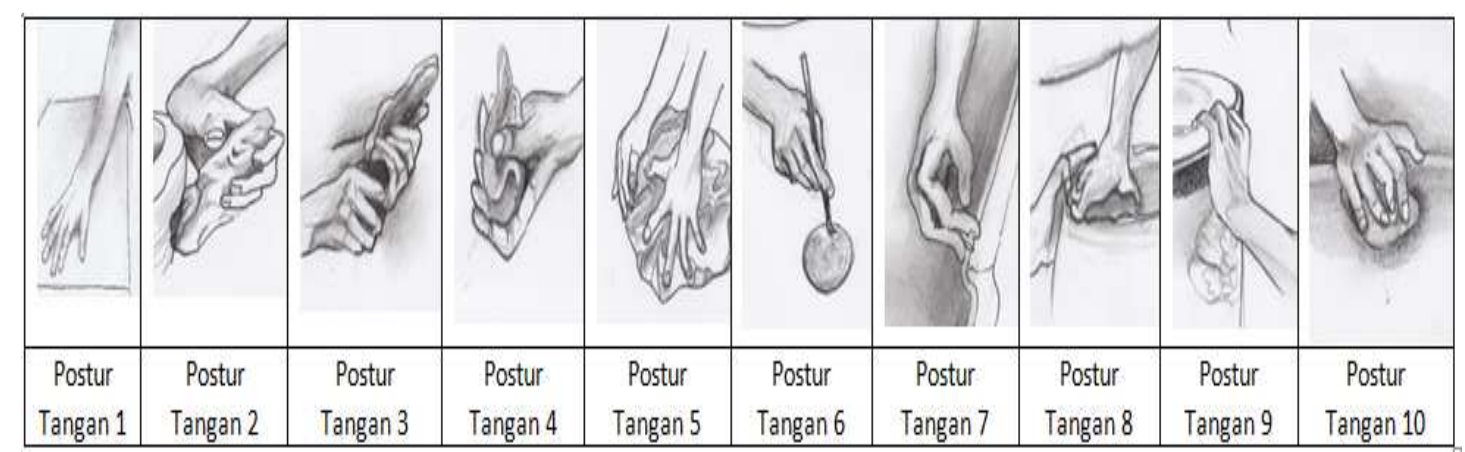

Gambar 1. Kondisi postur tangan
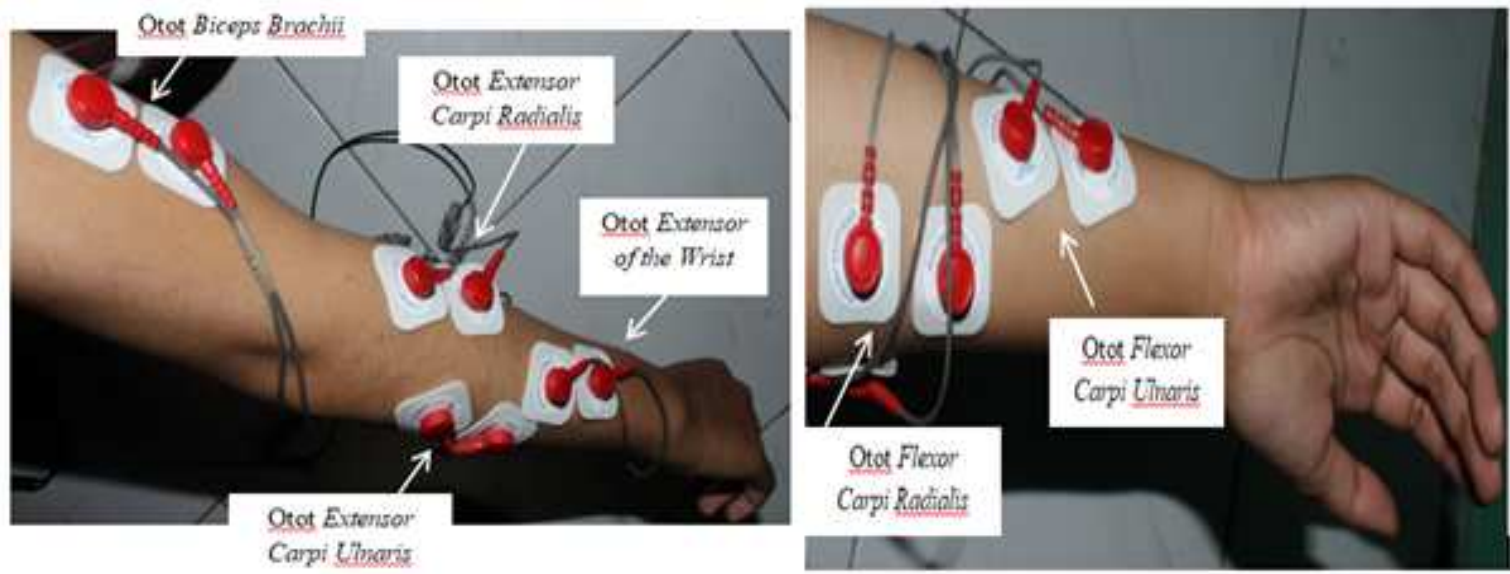

Gambar 2. Letak elektroda pada otot yang berpengaruh terhadap gerakan 
aktivitas otot antara laki-laki dan perempuan pada postur tangan menggunakan nilai root mean square (RMS) dan indeks simpangan nilai RMS dengan pengukuran surface electromyography.

\section{Metodologi}

Penelitian dilakukan pada industri pembuatan Gerabah di Desa Kasongan, Kecamatan Kasihan, Kabupaten Bantul, DIY. Responden yaitu 16 orang laki-laki dan 10 orang perempuan dengan usia rata-rata $33 \pm 16,9$ tahun, tinggi badan rata-rata $1,6 \pm 0,16$ meter, berat badan rata-rata $55,8 \pm 0$ kilogram, dan indeks massa tubuh rata-rata 21,05 $\pm 3,9$ (kategori berat badan normal).

\section{HASIL DAN PEMBAHASAN}

Data yang dikumpulkan, yaitu:

1. Pengambilan gambar postur kerja. Hasil capture kemudian dilakukan pemilihan postur tangan yang melibatkan otot tubuh bagian atas, diperoleh 10 variasi sikap tangan pekerja yang memang berbeda (Gambar 1).

2. Pengukuran kekuatan otot menggunakan sEMG. Tubuh manusia ketika melakukan gerakan, maka ada beberapa otot yang ikut berkontraksi. Pemilihan otot yang berkontraksi bergantung pada gerakan yang akan dilakukan. Pada posisi duduk melibatkan otot bagian bawah tubuh. Otot yang berpengaruh adalah (Gambar 2).

3. Segmen tubuh pada postur tangan, yang meliputi:

a. Kondisi lengan atas. Pada lengan atas terdapat tiga macam gerakan, yaitu: (1) abduction dan adduction, (2) flexion dan extension, (3) netral, medial rotation, dan lateral rotation (Kee \& Karwowski, 2001). Kesepuluh postur mengalami gerakan adduction, tetapi sudut yang dibentuk berbeda-beda, mulai dari sudut $0^{\circ}$ (postur 1 dan 4 ), sudut $10^{\circ}$ (postur 3 dan 6 ), sudut $20^{\circ}$ (postur 2), sudut $30^{\circ}$ (postur 9), sudut $45^{\circ}$ (postur 5, 8, dan 10), dan sudut $50^{\circ}$ (postur 7). Gerakan flexion dialami oleh 10 postur tangan dengan sudut yang berbeda, yaitu mulai dari sudut $0^{\circ}$ (postur 1 dan 4 ), sudut $10^{\circ}$ (postur 3 ), sudut $20^{\circ}$ (postur 6 ), sudut $45^{\circ}$ (postur 7 dan 10), dan sudut $60^{\circ}$ (postur 2, 5, 8, dan 9). Gerakan netral dilakukan oleh postur 1, 3, 5, dan 10. Selebihnya adalah gerakan medial rotation.

b. Kondisi siku. Gerakan pada siku dipengaruhi oleh dua hal, yaitu: (1) gerakan netral, flexion, dan extension, (2) gerakan pronation dan supination (Kee \& Karwowski, 2001). Kesepuluh postur tangan pada posisi netral (postur 1 dan 4) dan gerakan flexion dengan sudut yang dibentuk berbeda-beda, adalah: sudut $5^{\circ}$ (postur 5), sudut $45^{\circ}$ (postur 8, 9, dan 10), sudut $60^{\circ}$ (postur 7), sudut $90^{\circ}$ (postur 6), sudut $100^{\circ}$ (postur 3), dan semuanya membentuk gerakan pronation.

c. Kondisi pergelangan. Gerakan pada pergelangan ada dua tipe, yaitu: (1) netral, extension, dan flexion, (2) netral ulnar deviation dan radial deviation (Kee \& Karwowski, 2001). Kesepuluh postur yang mengalami gerakan netral (postur 1, 3, dan 4), gerakan extension dengan sudut $5^{\circ}$ (postur 6 ), sudut $20^{\circ}$ (postur 5), sudut $25^{\circ}$ (postur 10), sudut $40^{\circ}$ (postur 2, 7, 8, dan 9).

d. Kondisi jari tangan. Terdapat dua tipe gerakan pada jari tangan, yaitu: (1) flexion dan extension, (2) abduction dan adduction. Gerakan extension dilakukan pada postur 1, 8, dan 10 . Adapun postur lainnya melakukan gerakan flexion. Gerakan adduction dilakukan oleh kesepuluh postur tangan. 


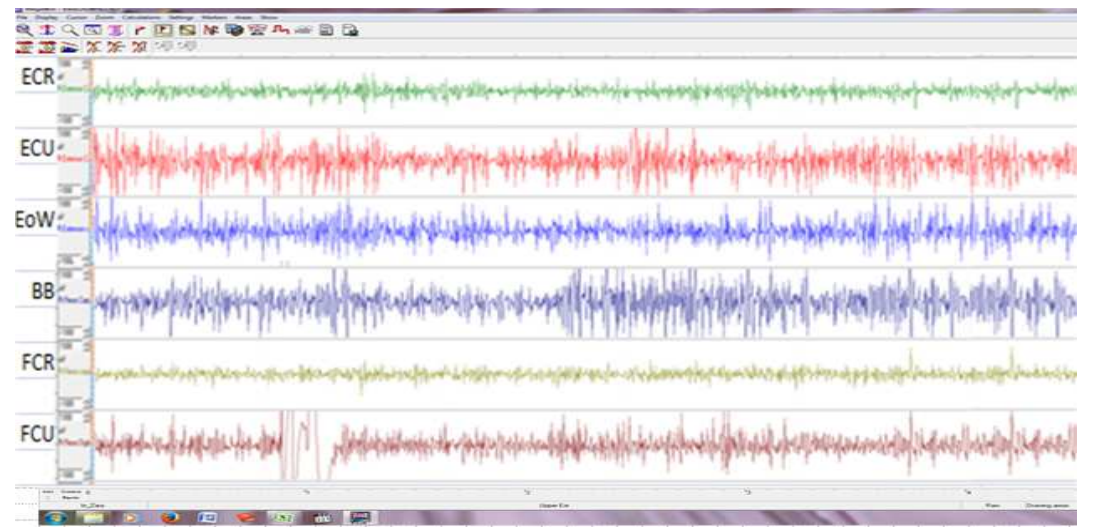

Gambar 3. Sinyal Listrik pada Postur Tangan Menggunakan sEMG

Tabel 1. Nilai RMS Pada Postur Kerja Bagian Tangan $(\mu \mathrm{V})$

\begin{tabular}{|c|c|c|c|c|c|c|c|c|c|c|c|}
\hline \multicolumn{12}{|c|}{ Postur } \\
\hline & & 1 & 2 & 3 & 4 & 5 & 6 & 7 & 8 & 9 & 10 \\
\hline \multirow[t]{2}{*}{ Extensor Carpi Radialis } & $\mathrm{L}$ & 13,91 & 74,81 & 18,58 & 19,01 & 35,14 & 29,51 & 93,17 & 138,01 & 107,91 & 72,84 \\
\hline & $\mathrm{P}$ & 13,54 & 74,28 & 17,37 & 18,14 & 31,06 & 20,04 & 91,53 & 124,28 & 97,58 & 70,16 \\
\hline \multirow[t]{2}{*}{ Extensor Carpi Ulnaris } & $\mathrm{L}$ & $49,34^{*}$ & $130,48^{*}$ & 123,54 & $133,64^{*}$ & $112,31^{*}$ & 66,18 & 97,99 & 61,68 & $108,89^{*}$ & 73,63 \\
\hline & $\mathrm{P}$ & $43,15^{* *}$ & $128,99^{* *}$ & 119,44 & 121,97 & $103,21^{* *}$ & 60,35 & 96,61 & 58,38 & $109,13^{* *}$ & 71,77 \\
\hline \multirow[t]{2}{*}{ Extensor of the wrist } & $\mathrm{L}$ & 24,52 & 74,41 & 94,52 & 84,11 & 108,15 & 42,04 & 37,62 & 38,91 & 31,01 & $111,36^{*}$ \\
\hline & $\mathrm{P}$ & 25,39 & 66,09 & 96,51 & 78,33 & 98,99 & 38,94 & 38,97 & 35,32 & 35,39 & $110,61^{* *}$ \\
\hline \multirow[t]{2}{*}{ Biceps Brachii } & $\mathrm{L}$ & 23,48 & 71,97 & 27,37 & 62,81 & 103,19 & $88,38^{*}$ & 34,82 & 149,46 & 77,58 & 33,51 \\
\hline & $\mathrm{P}$ & 23,05 & 69,89 & 28,86 & 52,81 & 93,19 & $74,82^{* * *}$ & 26,07 & 146,59 & 79,94 & 33,05 \\
\hline \multirow[t]{2}{*}{ Flexor Carpi Radialis } & $\mathrm{L}$ & 27,62 & 37,61 & $155,02^{*}$ & 131,01 & 92,95 & 51,82 & 45,04 & 34,75 & 38,83 & 67,88 \\
\hline & $\mathrm{P}$ & 24,54 & 34,61 & $158,65^{* * *}$ & $139,44^{* *}$ & 94,77 & 47,39 & 41,23 & 34,16 & 31,96 & 63,39 \\
\hline \multirow{2}{*}{ Flexor Carpi Ulnaris } & $\mathrm{L}$ & 23,22 & 53,06 & 138,31 & 69,86 & 82,02 & 61,95 & $105,41^{*}$ & $179,19^{*}$ & 70,72 & 38,06 \\
\hline & $\mathrm{P}$ & 24,75 & 46,17 & 128,38 & 67,65 & 72,91 & 66,59 & $107,74^{\text {*** }}$ & $169,46^{* *}$ & 70,14 & 38,02 \\
\hline
\end{tabular}

Keterangan: Nilai RMS Tertinggi tiap postur untuk ${ }^{*}$ laki-laki dan ${ }^{* *}$ perempuan, $\mathrm{L}=$ laki-laki, $\mathrm{P}=$ Perempuan

Pengambilan data untuk masing-masing otot menunjukkan sinyalnya, dengan satuan $\mu \mathrm{V}$ (Gambar 3), kemudian dihitung rata-rata pada Microsoft Excel yang selanjutnya dilakukan perhitungan nilai rata-rata RMS. Nilai RMS diperoleh dari menghitung akar kuadrat dan rerata aritmatika, untuk masingmasing otot setiap 16 responden laki-laki dan 10 responden perempuan, diperoleh hasil pada Tabel 1.

\section{Kondisi otot pada postur tangan}

Otot-otot upper extremity adalah otot yang menempel pada skapula ke dada dan berpengaruh terhadap bergeraknya lengan bawah, pergelangan tangan, dan tangan. Bagian tubuh yang termasuk upper extremity, adalah: kepala, tangan, lengan atas, lengan bawah, bahu, aksilla, regio pectoral, dan skapula. Terdapat lebih dari 20 otot yang menyebabkan sebagian besar pergelangan, tangan, dan gerakan jari terletak disepanjang lengan bawah (Cort, dkk., 2006).

a. Otot extensor carpi radialis (ECR). Hasil aktivitas otot ECR antara laki-laki dan perempuan tidak mengalami perbedaan secara signifikan. Nilai RMS untuk postur laki-laki cenderung lebih tinggi daripada untuk perempuan. Perbedaan tertinggi pada postur 6 yaitu 32,09\% berurutan dibawahnya adalah postur postur 5 yaitu $11,61 \%$ berikutnya postur 8 dengan nilai $9,95 \%$ dan postur 9 yaitu $9,57 \%$. Nilai persentase perbedaan antara laki-laki dan perempuan pada postur 2 yaitu $0,71 \%$. Nilai RMS untuk aktivitas otot ECR yang tertinggi dibanding otot lainnya ada pada postur 8 karena lengan mengalami adduction $45^{\circ}$ dan lengan flexion $60^{\circ}$ yaitu $138,01 \mu \mathrm{V}$ untuk laki-laki dan 124,28 $\mu \mathrm{V}$ untuk perempuan (Gambar 4). 


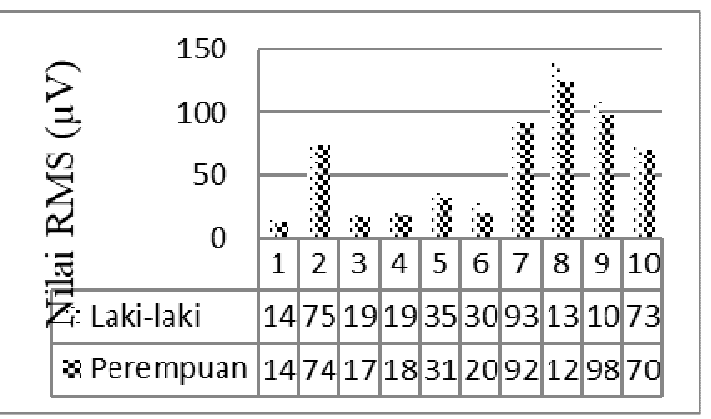

Gambar 4. Otot ECR pada postur tangan untuk lakilaki dan perempuan

b. Otot extensor carpi ulnaris (ECU). Otot ECU terdapat perbedaan nilai persentase antara laki-laki dengan perempuan yaitu pada postur 1 sebesar $12,55 \%$, postur 6 sebesar $8,81 \%$, postur 4 yaitu $8,73 \%$ dan postur 5 sebesar $8,10 \%$ dengan nilai lebih besar postur laki-laki dari pada perempuan, tetapi pada postur 9 nilai RMS untuk perempuan lebih besar 0,22\% daripada laki-laki. Aktivitas otot ECU tertinggi pada postur 4 sebesar $133,64 \mu \mathrm{V}$ untuk laki-laki dan postur 2 untuk perempuan yaitu $128,99 \mu \mathrm{V}$ untuk perempuan karena pada postur 4 bagian jari mengalami flexion (Gambar 5).

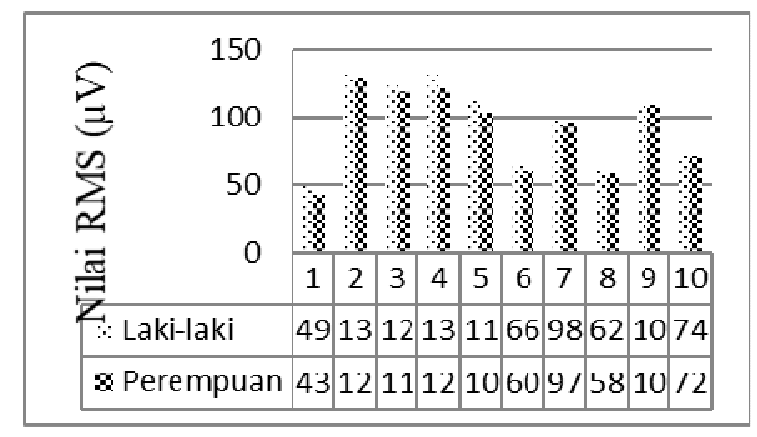

Gambar 5. Otot ECU pada postur tangan untuk lakilaki dan perempuan

c. Otot extensor of the wrist (EoW). Hasil sEMG pada otot EoW adalah ada dua postur yang berbeda signifikan antara postur laki-laki dan perempuan diatas $10 \%$ yaitu postur 2 sebesar 11,18\%. Adapun berurutan di bawahnya adalah postur 8 sebesar $9,23 \%$, postur 5 yaitu $8,47 \%$ dan postur 7 yaitu $7,37 \%$. Terdapat empat postur dimana nilai RMS nya lebih tinggi yang perempuan dibanding laki-laki yaitu postur 1 sebesar $3,55 \%$, postur 3 sebesar $2,11 \%$, postur 7 sebesar 3,59\% dan postur 9 sebesar 14,12\%. Aktivitas otot EoW pada postur10 mempunyai nilai RMS tertinggi sebesar $111,35 \mu \mathrm{V}$ untuk lakilaki dan 110,61 $\mu \mathrm{V}$ untuk perempuan karena lengan pada posisi medial dan jari mengalami extension (Gambar 6).

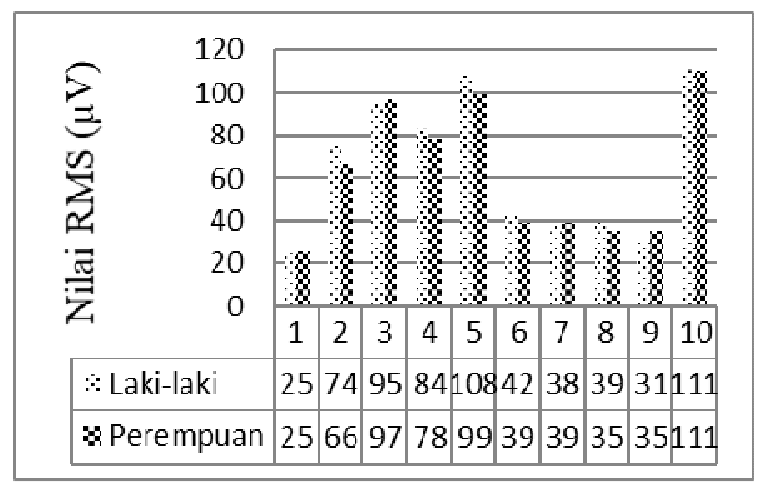

Gambar 6. Otot EoW pada postur tangan untuk lakilaki dan perempuan

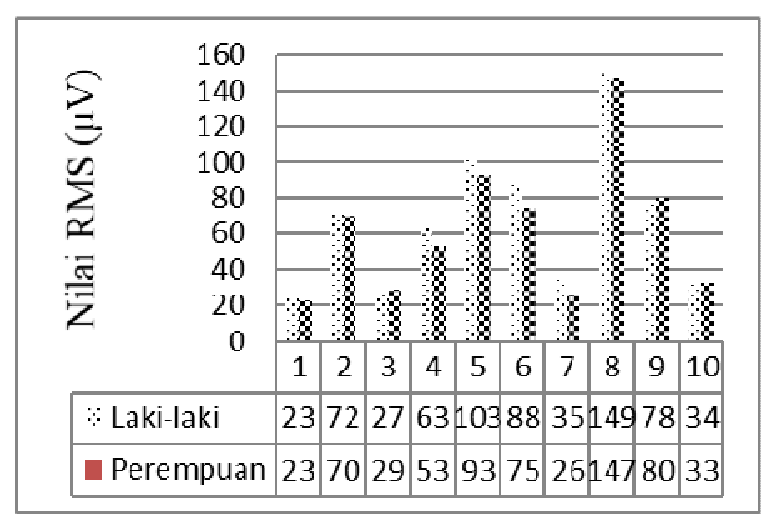

Gambar 7. Otot biceps brachii pada postur tangan untuk laki-laki dan perempuan

d. Otot biceps brachii. Hasil pengukuran aktivitas otot menggunakan sEMG diperoleh hasil nilai RMS terlihat pada Gambar 7. Nilai RMS untuk laki-laki dan perempuan mendekati pola yang hampir sama untuk sepuluh postur kerja bagian tangan. Terdapat empat perbedaan yang signifikan antara aktivitas otot laki-laki dengan perempuan, yaitu pada postur 7 sebesar $25,13 \%$, postur 4 sebesar $15,92 \%$, postur 6 sebesar $15,34 \%$ dan postur 5 sebesar 9,69\%. Nilai RMS dimana 
perempuan lebih tinggi daripada laki-laki terjadi pada postur 3 sebesar $5,44 \%$ dan postur 9 sebesar 3,04\%. Nilai RMS tertinggi pada postur 8 untuk laki-laki sebesar $149,45 \mu \mathrm{V}$ dan perempuan sebesar $146,59 \mu \mathrm{V}$, karena pada postur 8 lengan mengalami flexion $60^{\circ}$.

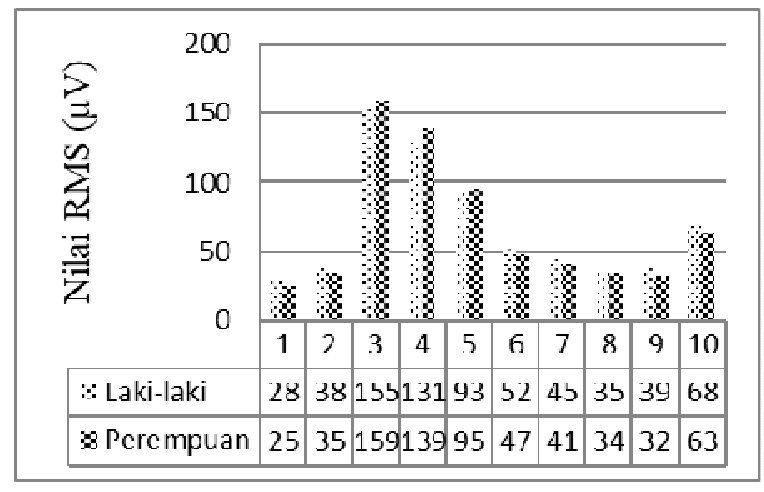

Gambar 8. Otot FCR pada postur tangan untuk lakilaki dan perempuan

e. Otot flexor carpi radialis (FCR). Nilai RMS pada aktivitas otot FCR hasil dari sEMG perbedaan terbesar antara laki-laki dengan perempuan pada postur 9 sebesar $17,69 \%$ dan postur 1 sebesar $11,15 \%$, postur 6 yaitu $8,55 \%$ dan postur 7 sebesar $8,46 \%$ sedangkan nilai RMS dengan perempuan lebih tinggi daripada laki-laki pada postur 3 sebesar $2,34 \%$, postur 4 sebesar 6,43\% dan postur 5 sebesar 1,96\% (Gambar 8). Nilai RMS tertinggi pada otot FCR adalah pada postur 3 untuk laki-laki sebesar $155,02 \mu \mathrm{V}$ dan perempuan sebesar
158,65 $\mu \mathrm{V}$ karena pergelangan netral tetapi jari mengalami gerakan flexion dan adduction.

f. Otot flexor carpi ulnaris (FCU). Nilai RMS pada otot FCU hasil dari sinyal sEMG perbedaan antara laki-laki dengan perempuan terbesar pada postur 2 sebesar $12,99 \%$ dan postur 5 sebesar $11,11 \%$, sedangkan untuk nilai perempuan yang lebih tinggi daripada laki-laki terdapat pada postur 1 sebesar $6,59 \%$, postur 6 sebesar 7,49\% dan postur 7 sebesar 2,21\% (Gambar 9). Nilai RMS tertinggi terdapat pada postur 8 untuk laki-laki sebesar $179,19 \mu \mathrm{V}$ dan perempuan $169,46 \mu \mathrm{V}$ karena pergelangan flexion dan adduction.

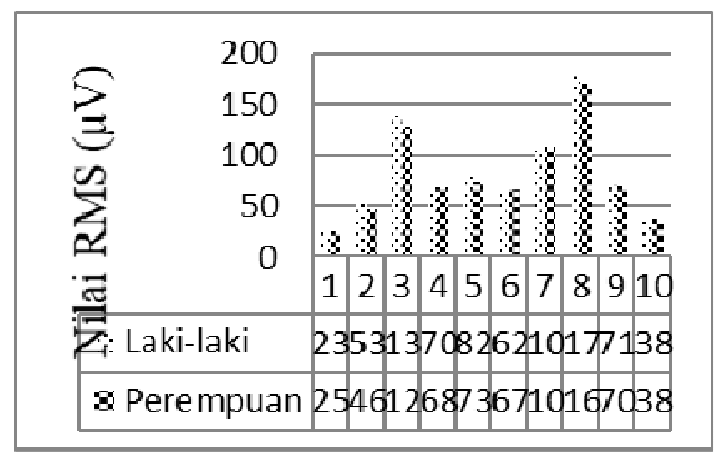

Gambar 9. Otot FCU pada postur tangan untuk lakilaki dan perempuan

Pada Tabel 1 terlihat bahwa aktivitas otot tertinggi yang diamati menggunakan sEMG adalah pada otot FCU pada postur 8 bahkan yang hasilnya $155,97 \mu \mathrm{V}$ untuk laki-laki dan $144,71 \mu \mathrm{V}$ untuk perempuan dibanding

Tabel 2. Indeks simpangan nilai RMS pada postur tangan

\begin{tabular}{lllrrrrrrrrr}
\hline \multicolumn{1}{c}{ Postur Tangan } & & $\mathbf{1}$ & $\mathbf{2}$ & $\mathbf{3}$ & $\mathbf{4}$ & $\mathbf{5}$ & $\mathbf{6}$ & $\mathbf{7}$ & $\mathbf{8}$ & \multicolumn{1}{c}{$\mathbf{9}$} & \multicolumn{1}{c}{$\mathbf{1 0}$} \\
\hline Extensor Carpi Radialis & $\mathrm{L}$ & 1 & $5,38^{*}$ & 1,34 & 1,37 & 2,53 & 2,12 & $6,70^{*}$ & $9,92^{* *}$ & $7,76^{* *}$ & $5,24^{* *}$ \\
& $\mathrm{P}$ & 1 & $5,49^{* *}$ & 1,28 & 1,34 & 2,29 & 1,48 & $6,76^{* *}$ & $9,18^{* *}$ & $7,21^{* *}$ & $5,18^{* *}$ \\
Extensor Carpi Ulnaris & $\mathrm{L}$ & 1 & 2,64 & 2,5 & 2,71 & 2,28 & 1,34 & 1,99 & 1,25 & 2,21 & 1,49 \\
& $\mathrm{P}$ & 1 & 2,99 & 2,77 & 2,83 & 2,39 & 1,4 & 2,24 & 1,35 & 2,53 & 1,66 \\
Extensor of the wrist & $\mathrm{L}$ & 1 & 3,03 & 3,85 & 3,43 & 4,41 & 1,71 & 1,53 & 1,59 & 1,26 & 4,54 \\
& $\mathrm{P}$ & 1 & 2,6 & 3,8 & 3,09 & 3,9 & 1,53 & 1,53 & 1,39 & 1,39 & 4,36 \\
Biceps Brachii & $\mathrm{L}$ & 1 & 3,07 & 1,17 & 2,68 & $4,39^{*}$ & $3,76^{*}$ & 1,48 & 6,37 & 3,3 & 1,43 \\
& $\mathrm{P}$ & 1 & 3,03 & 1,25 & 2,29 & $4,04^{* *}$ & $3,25^{* *}$ & 1,13 & 6,36 & 3,47 & 1,43 \\
Flexor Carpi Radialis & $\mathrm{L}$ & 1 & 1,36 & 5,61 & $4,74^{*}$ & 3,37 & 1,88 & 1,63 & 1,26 & 1,41 & 2,46 \\
& $\mathrm{P}$ & 1 & 1,41 & $6,46^{* *}$ & $5,68^{* *}$ & 3,86 & 1,93 & 1,68 & 1,39 & 1,3 & 2,58 \\
Flexor Carpi Ulnaris & $\mathrm{L}$ & 1 & 2,29 & $5,96^{*}$ & 3,01 & 3,53 & 2,67 & 4,54 & 7,72 & 3,05 & 1,64 \\
& $\mathrm{P}$ & 1 & 1,87 & 5,19 & 2,73 & 2,95 & 2,69 & 4,35 & 6,85 & 2,83 & 1,54 \\
\hline
\end{tabular}

Keterangan: Nilai tertinggi untuk postur tangan ("laki-laki, " perempuan), L=Laki-laki, $\mathrm{P}=$ Perempuan 
postur netralnya, data ini berbeda dengan pendapat (Cort et al., 2006) yang menyatakan bahwa otot lengan bawah extensor aktivitas ini lebih besar daripada flexor untuk gerakan yang menggunakan kurang dari $50 \%$ dari kekuatan genggam maksimal karena extensor sebagai stabiliser bersama.

\section{Indeks Simpangan Nilai RMS Postur Tangan}

Indeks simpangan nilai RMS merupakan perbandingan selisih antara postur tangan yang ada dengan postur tangan 1 sebagai postur dasar. Apabila hasil perbandingan selisih semakin besar, maka aktivitas otot semakin kuat karena semakin jauh jaraknya dengan postur dasar demikian pula sebaliknya (Tabel 2).

Pada Tabel 2 terlihat bahwa indeks simpangan nilai RMS tertinggi pada postur tangan 8 yaitu otot ECR, untuk laki-laki sebesar 9,92 dan untuk perempuan sebesar 9,18 . Pada postur tangan 8 posisi lengan terjadi gerakan aduksi (sudut $45^{\circ}$ ), fleksi (sudut $60^{\circ}$ ), dan rotasi medial. Posisi siku terjadi fleksi (sudut $45^{\circ}$ ) dan supination. Posisi pergelangan terjadi ekstensi (sudut $40^{\circ}$ ) dan deviasi radial. Posisi jari terjadi fleksi dan abduksi, maka aktivitas otot ECR lebih tinggi.

\section{SIMPULAN}

Otot yang berpengaruh pada postur kerja bagian tangan adalah: extensor carpi radialis, extensor carpi ulnaris, extensor of the wrist, biceps brachii, flexor carpi radialis, dan flexor carpi ulnaris. Nilai RMS dan indeks simpangan nilai RMS laki-laki lebih tinggi dibanding perempuan disetiap otot dan disetiap postur tangan.

\section{DAFTAR PUSTAKA}

Bartuzi, P.; Roman-liu, D.; Tokarski, T. (2007). "A study of the influence of muscle type and muscle force level on individual frequency bands of the EMG power spectrum". International Journal of Occupational Safety and Ergonomics. Vol. 13(3), pp.: $241-254$.
Criswell, E. (2011). Cram's Introduction to Surface Electromyography. Massachussete: Jones \& Bartlett Learning. Finneran, A.; Sullivan, L.O. (2013). "Effects of grip type and wrist posture on forearm EMG activity, endurance time and movement accuracy". International Journal of Industrial Ergonomics, Vol. 43 (1), pp.: 91 - 99.

Cort, J.A., Stephens, A.; Potvin, J.R. (2006). A biomechanical and psychophysical examination of fastener initiations in automotive assembly. International Journal of Industrial Ergonomics, 36(10), 837-845. http://doi.org/10.1016/j.ergon.2006.05.009. 